\title{
Effects of gonadotropin-releasing hormone analog (GnRHa) immunization on the gonadal transcriptome and proteome of tilapia (Oreochromis niloticus)
}

\section{Rui Wang}

Guangxi Academy of Fishery Sciences

\section{Luting Wen}

Guangxi Academy of Fishery Sciences

\section{Huawei Ma}

Guangxi Academy of Fishery Sciences

Huizan Yang ( $\nabla$ yhzyang@163.com )

Guangxi Institution of Fishery Science

Min Lv

Guangxi Academy of Fishery Sciences

\section{Zhong Chen}

Guangxi Academy of Fishery Sciences

\section{Xuesong Du}

Guangxi Academy of Fishery Sciences

\section{Lan Zeng}

Guangxi Academy of Fishery Sciences

\section{Yong Lin}

Guangxi Academy of Fishery Sciences

\section{Liming Huang}

Guangxi Academy of Fishery Sciences

\section{Tao Chen}

Nanning University

\section{Research article}

Keywords: tilapia, GnRHa, sex control, transcriptomics, proteomics

Posted Date: March 31st, 2020

DOI: https://doi.org/10.21203/rs.3.rs-18227/v1

License: (a) This work is licensed under a Creative Commons Attribution 4.0 International License. Read Full License 
Version of Record: A version of this preprint was published at Comparative Biochemistry and Physiology Part D: Genomics and Proteomics on March 1st, 2021. See the published version at https://doi.org/10.1016/j.cbd.2020.100780. 


\section{Abstract}

Background: Gonadotropin releasing hormone $(\mathrm{GnRH})$ plays an important role in the regulation of vertebrate reproduction. Studies have shown that immunization against $\mathrm{GnRHa}$ can induce sexually sterile tilapia. To explore the mechanism behind this, in this study, RNA-seq and data-independent acquisition (DIA) techniques were used to study the transcriptome and proteome of the gonad of tilapia immunized with GnRHa.

Results : 644 differentially expressed genes (80 upregulated and 564 downregulated) and 1150 differentially expressed proteins (351 upregulated and 799 downregulated) were identified. There were 209 genes with consistent differential expression patterns in the transcriptomic and proteomic analyses, of which 9 were upregulated and 200 downregulated, indicating that the gonad gene expression was inhibited by $\mathrm{GnRHa}$ immunization. The downregulated genes were particularly involved in the functions of single-organism process, binding, cellular process, metabolic process and catalytic activity, and associated with the pathways including ECM-receptor interaction, focal adhesion, cardiac muscle contraction and oxidative phosphorylation. The expression of six differentially expressed genes involved in the $\mathrm{GnRH}$ signaling pathway was all downregulated. In addition, several important functional genes related to gonadal development after GnRHa immunization were screened.

Conclusions: This study confirmed the expression of corresponding genes was affected by GnRHa on the gonad development in tilapia at the molecular level, and laid a foundation for elucidating the mechanism of GnRHa immunization.

\section{Background}

Gonadotropin releasing hormone $(\mathrm{GnRH})$ is a neurohormone secreted by hypothalamic neurons, which plays important roles in the regulation of vertebrate reproduction. It is transported to the portal vein system through axons, flows into the anterior pituitary through blood vessels, binds to the $\mathrm{GnRH}$ receptor (GnRHR) on gonadotropin cells in the pituitary, and stimulates the synthesis and secretion of follicle-stimulating hormone (FSH) and luteinizing hormone (LH) [1]. GnRH is a small-molecule polypeptide with weak immunogenicity, however, coupling with macromolecular protein carriers can improve its immunogenicity and induce immunized animals to produce $\mathrm{GnRH}$ antibodies [2]. $\mathrm{GnRH}$ antibody can neutralize endogenous $\mathrm{GnRH}$, leading to infertility in male and female mammals [3]. The efficiency of GnRH purification is low due to the low content of endogenous $\mathrm{GnRH}$, and synthetic gonadotropin releasing hormone analog ( $\mathrm{GnRHa}$ ) is often used as a clinical alternative. GnRHa not only retains the physiological functions of $\mathrm{GnRH}$, but also exhibits a prolonged half-life and improved capacity to bind to $\mathrm{GnRH}$ receptors [4]. GnRHa antigen with good immunogenicity can be prepared by coupling GnRHa with bovine serum albumin (BSA) and emulsifying with Freund's incomplete adjuvant [5]. GnRH immunization is considered to be an effective method to improve the growth performance of cultured animals, improve meat quality, control reproduction, and prevent undesired sexual behavior $[6,7]$. The reproduction of fish is regulated by the release of gonadotropin from the pituitary induced by $\mathrm{GnRH}$ released from the hypothalamus [8]. Studies have shown that fish have two or three forms of GnRH [9], of which one or two forms can be found in the pituitary [10]. However, few reports have been published on the regulatory effect of $\mathrm{GnRH}$ immunization on the reproductive function of fish. 
Tilapia is one of the most important freshwater culture varieties, exhibiting the advantages of rapid growth and strong stress resistance, which is an international fish that the Food and Agriculture Organization of the United Nations focuses on promoting aquaculture [11]. However, owing to its early sexual maturity and rapid breeding cycle, the reproductive behavior of tilapia in mixed-sex culture consumes a lot of energy, which interferes with growth, and at the same time leads to very different qualities of harvested tilapia, a low commodity rate, and a high feed conversion ratio, greatly reducing the product quality and associated economic benefits [12]. As such, it is important to obtain sterile individuals to eliminate the adverse effects of sexual maturity and reproductive behavior of tilapia. Our previous studies showed that the level of GnRH antibody in the GnRHa immunized group was significantly higher than that in the negative control group [13]. To further investigate the mechanism behind the effects of $\mathrm{GnRHa}$ immunization in tilapia, the transcriptome and proteome of gonad of tilapia after GnRHa immunization were analyzed, and the genes with functions that are particularly important for gonad development of tilapia were screened. The results confirmed the expression of corresponding genes was affected by GnRHa on gonad development at the molecular level, and laid a foundation for elucidating the mechanism of GnRHa immunization.

\section{Results}

\section{RNA-seq}

The quality control results of the original data of RNA-seq showed that a total of 375.2 million clean reads were obtained from the eight samples after preliminary filtration, and the average number of clean reads per sample was 46.9 million (ranging from 35.9 to 59.5 million). Overall, $98.45-98.98 \%$ high-quality clean reads were obtained after further filtration of the clean reads, and the filtered reads included $0.31-0.36 \%$ reads containing an adapter, $0.71-1.21 \%$ low-quality reads (containing more than $50 \%$ bases with Qvalue $\leq 20$ ), and 53-148 reads containing all A, no reads containing more than $10 \% \mathrm{~N}$. After quality control, the data were considered to be of sufficient quality to be used for subsequent analysis. Owing to the sample quality and species, the efficiency of removing ribosomal RNA might not be stable, and the contamination of ribosomal RNA would affect the subsequent analysis. Therefore, the read alignment tool was applied to align highquality clean reads to the ribosome of the species (mismatch number: 0 ), and the aligned reads were removed; the remaining data were used for subsequent analysis. The alignment results showed that the proportion of unmapped reads obtained from the samples was $98.35-99.81 \%$. The high-quality clean reads without ribosomal RNA were aligned to the reference genome (GCF_001858045.2) of tilapia using TopHat2 (2.1.1), the results of which are shown in Table 1. There were 10.95-13.36\% unmapped reads, $85.54-88.00 \%$ uniquely mapped reads, and $1.05-1.78 \%$ multiple mapped reads, resulting in an overall mapping rate of $86.64-89.05 \%$. 
Table 1

Genome comparison statistics

\begin{tabular}{|llllll|}
\hline Sample & $\begin{array}{l}\text { Total } \\
\text { Reads }\end{array}$ & $\begin{array}{l}\text { Unmapped } \\
\text { Reads }\end{array}$ & $\begin{array}{l}\text { Unique Mapped } \\
\text { Reads }\end{array}$ & $\begin{array}{l}\text { Multiple Mapped } \\
\text { reads }\end{array}$ & $\begin{array}{l}\text { Mapping } \\
\text { Ratio }\end{array}$ \\
\hline CK-1 & 36590112 & $\begin{array}{l}4886623 \\
(13.36 \%)\end{array}$ & $31300681(85.54 \%)$ & $402808(1.10 \%)$ & $86.64 \%$ \\
CK-2 & 47379594 & $\begin{array}{l}5866217 \\
(12.38 \%)\end{array}$ & $40972731(86.48 \%)$ & $540646(1.14 \%)$ & $87.62 \%$ \\
\hline CK-3 & 38326808 & $\begin{array}{l}4471997 \\
(11.67 \%)\end{array}$ & $33337199(86.98 \%)$ & $517612(1.35 \%)$ & $88.33 \%$ \\
CK-4 & 35287440 & $\begin{array}{l}3998243 \\
(11.33 \%)\end{array}$ & $30883381(87.52 \%)$ & $405816(1.15 \%)$ & $88.67 \%$ \\
\hline T1-1 & 54158908 & $\begin{array}{l}6050754 \\
(11.17 \%)\end{array}$ & $47145836(87.05 \%)$ & $962318(1.78 \%)$ & $88.83 \%$ \\
\hline T1-2 & 45581802 & $\begin{array}{l}5197612 \\
(11.40 \%)\end{array}$ & $39648236(86.98 \%)$ & $735954(1.61 \%)$ & $88.60 \%$ \\
\hline T1-3 & 58683152 & $\begin{array}{l}6760559 \\
(11.52 \%)\end{array}$ & $51057149(87.00 \%)$ & $865444(1.47 \%)$ & $88.48 \%$ \\
\hline T1-4 & 51930932 & $\begin{array}{l}5684817 \\
(10.95 \%)\end{array}$ & $45700263(88.00 \%)$ & $545852(1.05 \%)$ & $89.05 \%$ \\
\hline
\end{tabular}

\section{Gene statistics}

The alignment results of the protein-coding genes of each sample are shown in Table 2. The total number of genes from the reference genome was 29,550, and 28,209 known genes (95.46\%) and 1796 unknown genes were detected in the sequencing results. The total number of genes in the immunized group (T1) was 29,370, including 27,603 known genes (93.41\%) and 1767 unknown ones, while the total number of genes in the control group (CK) was 28,363 , including 26,810 known genes (92.73\%) and 1553 unknown ones. 
Table 2

Numbers of detected genes in each sample

\begin{tabular}{|llll|}
\hline Sample Name & Known Gene Num & New Gene Num & All Gene Num \\
\hline CK-1 & $24056(81.41 \%)$ & 1326 & 25382 \\
\hline CK-2 & $24460(82.77 \%)$ & 1322 & 25782 \\
\hline CK-3 & $24245(82.05 \%)$ & 1303 & 25548 \\
\hline CK-4 & $24031(81.32 \%)$ & 1344 & 25375 \\
\hline T1-1 & $22592(76.45 \%)$ & 1332 & 23924 \\
\hline T1-2 & $22712(76.86 \%)$ & 1233 & 23945 \\
\hline T1-3 & $23968(81.11 \%)$ & 1333 & 25301 \\
\hline T1-4 & $25996(87.97 \%)$ & 1139 & 27135 \\
\hline
\end{tabular}

\section{Identification of DEGs}

In this study, edgeR software was used to analyze the difference of gene expression between the groups, and FDR and $\log _{2}$ FC were used to screen the DEGs. A total of 644 DEGs were obtained. As shown in Fig. 1, 80 upregulated genes and 564 downregulated genes were identified in the immunized group (T1), compared with the control group (CK).

\section{GO and KEGG analyses of DEGs}

The DEGs were annotated by GO, and then the upregulated and downregulated genes was conducted by the GO term classification. The results (Fig. 2) showed that the upregulated genes were mainly involved in catalytic activity (13 genes) and metabolic process (11 genes), while the downregulated genes were mainly related to single-organism process (116 genes), binding (113 genes), cellular process (103 genes), metabolic process (83 genes), and catalytic activity (73 genes).

Functional enrichment analysis of the DEGs revealed the 20 most enriched pathways, as shown in Fig. 3 . The RichFactor indicates the ratio of the number of differentially expressed transcripts enriched in the pathway relative to the total number of transcripts enriched in the pathway; a higher RichFactor indicates a higher degree of enrichment. QValue is the $\mathrm{P}$ value after correction for multiple testing, which ranges from 0 to $1 ; \mathrm{a}$ smaller QValue indicates more significant enrichment. The 20 pathways with the smallest Qvalue are shown in Fig. 3. The 20 enriched pathways included ECM-receptor interaction ( 24 related genes), focal adhesion (30 related genes), cardiac muscle contraction (15 related genes), oxidative phosphorylation (10 related genes), regulation of actin cytoskeleton ( 16 related genes), adrenergic signaling in cardiomyocytes (13 related genes), steroid hormone biosynthesis ( 5 related genes), phagosome (14 related genes), PPAR signaling pathway (5 related genes), GnRH signaling pathway (6 related genes), glycosaminoglycan biosynthesis - chondroitin sulfate/dermatan sulfate (2 related genes), a-linolenic acid metabolism (2 related genes), ether lipid metabolism (3 related genes), endocytosis (14 related genes), cytokine-cytokine receptor interaction (12 related genes), cell adhesion molecules (CAMs; 13 related genes), arginine and proline metabolism (3 related 
genes), $\beta$-alanine metabolism (2 related genes), gap junction (5 related genes), and arachidonic acid metabolism (4 related genes).

The six $\mathrm{GnRH}$ signaling pathway-related genes were epidermal growth factor receptor, transcript variant $\mathrm{X} 1$ (EGFR), matrix metalloproteinase-14 (MT1), matrix metallopeptidase 2 (MMP2), transcription factor AP-1 (cJun), voltage-dependent L-type calcium channel subunit alpha-1D-like (CACN), and cytosolic phospholipase A2 gamma-like (PLA2); their locations in the GnRH signaling pathway are shown in Fig. 4.

\section{Identification of DEPs}

Quality control of the original mass spectrometry data was carried out using QuiC software (Biognosys), and the similarity of quality control indexes between samples was determined. Then, a library was established based on the data obtained by DDA mode using Pulsar software, and was used for the quantification of subsequent DIA data. The identification standard of proteins was as follows: peptide precursor threshold $1.0 \%$ FDR and protein threshold 1.0\% FDR. There were a total of 70,334 peptide precursors, 56,726 peptides, 5,700 protein groups, and 10,468 proteins. The local normalization method in Pulsar software was used to normalize the quantitative results of peptide DIA in all samples and eliminate the systematic errors. The expression of a protein was the median of the relative expression of all unique peptides of the protein. The annotation of identified proteins included GO annotation, pathway annotation, and COG/KOG annotation. The screening threshold of DEPs was more than 1.5 times the absolute value of the relative quantitative values and Student's t-test Qvalue < 0.05. A total of 1,150 DEPs were identified, of which 351 were upregulated and 799 were downregulated in T1, compared with CK (Fig. 1).

\section{GO and KEGG analyses of DEPs}

The DEPs were annotated to GO terms, which were then classified according to the up- or downregulation (Fig. 5). The results showed that the DEPs were mainly enriched in metabolic process (53 upregulated and 181 downregulated), single-organism process (35 upregulated and 149 downregulated), and cellular process (53 upregulated and 153 downregulated). The upregulated and downregulated proteins within the category of molecular function were mainly related to catalytic activity (39 upregulated and 134 downregulated) and binding (56 upregulated and 126 downregulated), while the upregulated and downregulated genes within the category of cellular component were mainly related to organelle (16 upregulated and 68 downregulated), cell (34 upregulated and 91 downregulated), and cell part (34 upregulated and 91 downregulated).

According to the pathway enrichment analysis of DEPs, the 20 most enriched pathways were determined, as shown in Fig. 6. These included 33 involved in protein processing in endoplasmic reticulum, 11 in protein export, 122 in metabolic pathways, 16 in fatty acid degradation, 13 in PPAR signaling pathway, 5 in fatty acid biosynthesis, 7 in N-glycan biosynthesis, 13 in peroxisome, 11 in fatty acid metabolism, 23 in oxidative phosphorylation, 4 in dorsal-ventral axis formation, 16 in lysosome, 9 in arginine and proline metabolism, 4 in other glycan degradation, 7 in glycerolipid metabolism, 3 in glycosaminoglycan degradation, 10 in ECMreceptor interaction, 9 in amino sugar and nucleotide sugar metabolism, 9 in myocardial contraction, and 7 in propionate metabolism.

\section{Correlation analysis of transcriptome and proteome in tilapia}


The correlations of the transcriptome and proteome of tilapia in the immunized group and the control group were analyzed, and functional enrichment analysis of the related gene sets was carried out. The results are shown in Fig. 7. The findings for a total of 209 mRNAs were consistent with the differential expression pattern of the corresponding proteins, of which 9 were upregulated and 200 were downregulated. Significance analysis showed that the findings of $48 \mathrm{mRNAs}$ were consistent with the differential expression patterns of the corresponding proteins, of which 1 was upregulated and 47 were downregulated. The detailed information of the genes with a consistent pattern are shown in Table 3. 
Table 3

Genes with a consistent pattern of differential expression between transcriptome and proteome

\section{No. mRNA $^{\mathrm{a}}$ Protein $^{\mathrm{a}}$ Description Pathway}

upregulated

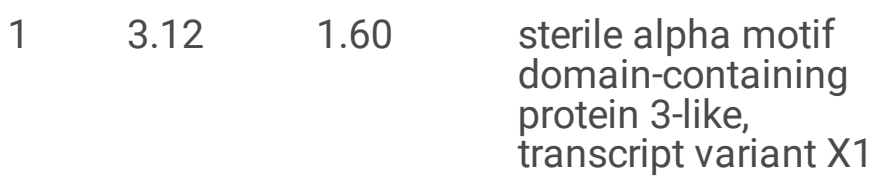

downregulated

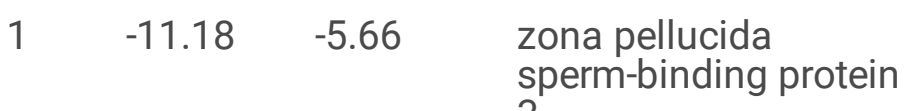

3

$2 \quad-10.81 \quad-1.37 \quad$ apolipoprotein A-I

$\begin{array}{llll}3 & -9.12 & -1.47 \quad \text { uncharacterized }\end{array}$

LOC109201766

$\begin{array}{llll}4 & -6.57 & -0.88 & \mathrm{NADH}\end{array}$

dehydrogenase

subunit 4

ko01100//Metabolic pathways;ko00190//Oxidative phosphorylation

$5 \quad-5.85 \quad-0.62 \quad$ actin, cytoplasmic 1

ko04145//Phagosome;ko04810//Regulation of actin cytoskeleton;ko04510//Focal

adhesion;ko04530//Tight

junction;ko04520//Adherens junction

\begin{tabular}{|c|c|c|c|c|}
\hline 6 & -5.45 & -1.00 & $\begin{array}{l}\text { betaine- } \\
\text { homocysteine S- } \\
\text { methyltransferase } 1\end{array}$ & $\begin{array}{l}\text { ko01100//Metabolic pathways;ko00270//Cysteine } \\
\text { and methionine metabolism;ko00260//Glycine, } \\
\text { serine and threonine metabolism }\end{array}$ \\
\hline 7 & -5.29 & -0.88 & apolipoprotein A-I & ko03320//PPAR signaling pathway \\
\hline 8 & -4.90 & -1.28 & $\begin{array}{l}\text { Ladderlectin, } \\
\text { transcript variant X1 }\end{array}$ & - \\
\hline 9 & -4.66 & -1.35 & $\begin{array}{l}\text { Actin, alpha, cardiac } \\
\text { muscle } 1\end{array}$ & $\begin{array}{l}\text { ko04261//Adrenergic signaling in } \\
\text { cardiomyocytes;ko04260//Cardiac muscle } \\
\text { contraction }\end{array}$ \\
\hline 10 & -4.58 & -1.45 & $\begin{array}{l}\text { type- } 4 \text { ice-structuring } \\
\text { protein }\end{array}$ & - \\
\hline 11 & -4.36 & -2.50 & $\begin{array}{l}\text { proteasome subunit } \\
\text { beta type- } 9\end{array}$ & ko03050//Proteasome \\
\hline 12 & -4.29 & -0.60 & integrin alpha-X & ko04810//Regulation of actin cytoskeleton \\
\hline 13 & -4.19 & -1.14 & $\begin{array}{l}\text { immunoglobulin } \\
\text { lambda-1 light chain- } \\
\text { like }\end{array}$ & - \\
\hline
\end{tabular}

a: Log 2-fold change of differentially expression 


\begin{tabular}{|c|c|c|c|c|}
\hline No. & $\mathrm{mRNA}^{\mathrm{a}}$ & Protein $^{a}$ & Description & Pathway \\
\hline 14 & -3.94 & -2.05 & $\begin{array}{l}\text { seminal plasma } \\
\text { glycoprotein } 120\end{array}$ & - \\
\hline 15 & -3.74 & -1.00 & $\begin{array}{l}\text { NADH } \\
\text { dehydrogenase } \\
\text { subunit } 2\end{array}$ & $\begin{array}{l}\text { ko01100//Metabolic pathways;ko00190//Oxidative } \\
\text { phosphorylation }\end{array}$ \\
\hline 16 & -3.58 & -2.40 & retbindin & ko04144//Endocytosis \\
\hline 17 & -3.53 & -3.49 & $\begin{array}{l}\text { extracellular matrix } \\
\text { protein } 1\end{array}$ & - \\
\hline 18 & -2.87 & -0.64 & $\begin{array}{l}\text { prolyl 4-hydroxylase } \\
\text { subunit alpha } 1\end{array}$ & $\begin{array}{l}\text { ko01100//Metabolic pathways;ko00330//Arginine } \\
\text { and proline metabolism }\end{array}$ \\
\hline 19 & -2.85 & -1.67 & $\begin{array}{l}\text { linkage group } 7 \\
\text { C11orf96 homolog }\end{array}$ & - \\
\hline 20 & -2.79 & -2.61 & $\begin{array}{l}\text { hydroxysteroid } 17- \\
\text { beta dehydrogenase } \\
1\end{array}$ & $\begin{array}{l}\text { ko01100//Metabolic pathways;ko00140//Steroid } \\
\text { hormone biosynthesis }\end{array}$ \\
\hline 21 & -2.76 & -0.77 & $\begin{array}{l}15- \\
\text { hydroxyprostaglandin } \\
\text { dehydrogenase } \\
{[\mathrm{NAD}(+)] \text {, transcript }} \\
\text { variant X2 }\end{array}$ & - \\
\hline 22 & -2.35 & -1.10 & $\begin{array}{l}\text { extracellular matrix } \\
\text { protein } 1\end{array}$ & - \\
\hline 23 & -2.29 & -1.04 & progesterone receptor & $\begin{array}{l}\text { ko04114//Oocyte meiosis;ko04914//Progesterone- } \\
\text { mediated oocyte maturation }\end{array}$ \\
\hline 24 & -2.19 & -0.85 & $\begin{array}{l}\text { NADH-cytochrome b5 } \\
\text { reductase } 2\end{array}$ & $\begin{array}{l}\text { ko00520//Amino sugar and nucleotide sugar } \\
\text { metabolism }\end{array}$ \\
\hline 25 & -2.13 & -1.26 & $\begin{array}{l}\text { gap junction } \mathrm{Cx} 32.7 \\
\text { protein }\end{array}$ & ko04540//Gap junction \\
\hline 26 & -2.12 & -0.71 & $\begin{array}{l}\text { Elastin, transcript } \\
\text { variant X1 }\end{array}$ & - \\
\hline 27 & -2.10 & -0.67 & glucose transporter & ko04920//Adipocytokine signaling pathway \\
\hline 28 & -2.03 & -0.95 & $\begin{array}{l}\text { progesterone receptor } \\
\text { membrane } \\
\text { component } 1\end{array}$ & - \\
\hline 29 & -2.03 & -1.46 & $\begin{array}{l}\text { synuclein gamma, } \\
\text { transcript variant } X 2\end{array}$ & - \\
\hline 30 & -1.94 & -0.68 & $\begin{array}{l}\text { carboxypeptidase } \mathrm{N} \\
\text { subunit } 1\end{array}$ & - \\
\hline
\end{tabular}

a: Log 2-fold change of differentially expression 


\begin{tabular}{|c|c|c|c|c|}
\hline No. & $\mathrm{mRNA}^{\mathrm{a}}$ & Protein $^{a}$ & Description & Pathway \\
\hline 31 & -1.88 & -0.72 & $\begin{array}{l}\text { procollagen C- } \\
\text { endopeptidase } \\
\text { enhancer } 2\end{array}$ & - \\
\hline 32 & -1.84 & -1.42 & $\begin{array}{l}\text { switch-associated } \\
\text { protein } 70\end{array}$ & - \\
\hline 33 & -1.73 & -2.83 & $\begin{array}{l}\text { complement receptor } \\
\text { type } 1 \text {, transcript } \\
\text { variant X1 }\end{array}$ & - \\
\hline 34 & -1.64 & -0.64 & $\begin{array}{l}\text { collagen alpha-4(IV) } \\
\text { chain }\end{array}$ & $\begin{array}{l}\text { ko04510//Focal adhesion;ko04512//ECM-receptor } \\
\text { interaction }\end{array}$ \\
\hline 35 & -1.62 & -1.70 & selenoprotein $\mathrm{P}$ & - \\
\hline 36 & -1.59 & -1.24 & $\begin{array}{l}\text { thymosin beta } 4 \mathrm{X} \text { - } \\
\text { linked }\end{array}$ & ko04810//Regulation of actin cytoskeleton \\
\hline 37 & -1.57 & -1.50 & $\begin{array}{l}\text { thrombospondin } \\
\text { type- } 1 \text { domain- } \\
\text { containing protein } 4\end{array}$ & - \\
\hline 38 & -1.55 & -1.07 & beta-2-microglobulin & - \\
\hline 39 & -1.50 & -1.71 & $\begin{array}{l}\text { thrombospondin- } 1 \mathrm{~b} \text {, } \\
\text { transcript variant } \mathrm{X} 1\end{array}$ & $\begin{array}{l}\text { ko04145//Phagosome;ko04510//Focal } \\
\text { adhesion;k004512//ECM-receptor } \\
\text { interaction;k004350//TGF-beta signaling } \\
\text { pathway;k004115//p53 signaling pathway }\end{array}$ \\
\hline 40 & -1.48 & -1.37 & $\begin{array}{l}\text { peptidyl-prolyl cis- } \\
\text { trans isomerase } \\
\text { FKBP10 }\end{array}$ & - \\
\hline 41 & -1.18 & -1.11 & $\begin{array}{l}\text { laminin subunit beta- } \\
1, \text { transcript variant } \\
\mathrm{X} 1\end{array}$ & $\begin{array}{l}\text { ko04510//Focal adhesion;ko04512//ECM-receptor } \\
\text { interaction }\end{array}$ \\
\hline 42 & -1.14 & -0.73 & $\begin{array}{l}\text { integrin subunit alpha } \\
\text { V, transcript variant } \\
\text { X1 }\end{array}$ & $\begin{array}{l}\text { ko04514//Cell adhesion molecules } \\
\text { (CAMs);ko04145//Phagosome;ko04810//Regulation } \\
\text { of actin cytoskeleton;ko04510//Focal } \\
\text { adhesion;ko04512//ECM-receptor interaction }\end{array}$ \\
\hline 43 & -1.12 & -1.42 & $\begin{array}{l}\text { secreted protein } \\
\text { acidic and cysteine } \\
\text { rich }\end{array}$ & - \\
\hline 44 & -1.11 & -1.44 & $\begin{array}{l}\text { serpin family } E \\
\text { member, transcript } \\
\text { variant } X 1\end{array}$ & - \\
\hline 45 & -1.03 & -1.32 & $\begin{array}{l}\text { Cystatin, transcript } \\
\text { variant X1 }\end{array}$ & - \\
\hline 46 & -1.01 & -2.71 & $\begin{array}{l}\text { golgin } A 4 \text {, transcript } \\
\text { variant } X 1\end{array}$ & - \\
\hline
\end{tabular}

a: Log 2-fold change of differentially expression 


\begin{tabular}{|c|c|c|c|c|}
\hline No. & $\mathrm{mRNA}^{\mathrm{a}}$ & Protein $^{a}$ & Description & Pathway \\
\hline 47 & -1.01 & -1.36 & $\begin{array}{l}\text { ribosomal protein } \\
\text { L39 }\end{array}$ & ko03010//Ribosome \\
\hline \multicolumn{5}{|c|}{ a: Log 2-fold change of differentially expression } \\
\hline
\end{tabular}

To further validate the results from the RNA sequencing data, six genes were selected for qRT-PCR analysis. Of the six selected genes, all showed similar expression patterns in the qRT-PCR analysis as observed from RNAseq data (Fig. 8). The statistical analysis also showed very good correlation $(r=0.997)$ between the two types of analysis.

\section{Discussion}

In addition to genetic factors, external environmental factors also play important roles in the sex determination and differentiation of fish. Therefore, fish can be useful subjects to study sexual differentiation. With the continuous progress and development of transcriptomic and proteomic technologies, transcriptomics and proteomics have been widely used in the study of reproductive and sexual differentiation-related mechanisms in fish, including tilapia, especially in the identification of DEGs, the screening of functional genes, and the discovery and verification of important regulatory pathways [14-17]. After treatment with progesterone receptor inhibitor (RU486), 7148 genes were differentially expressed in gonad of female tilapia; the results revealed that fshr and Ihr were significantly downregulated and ars was significantly upregulated after RU486 treatment, which might account for the masculinization and infertility of female fish [18]. Transcriptomic analysis of the gonads of female and male tilapia at different developmental stages revealed that estrogen may play an important role in female sex determination and maintenance of phenotypic sex, which lays the foundation for future studies into the molecular mechanisms of sex determination and maintenance of phenotypic sex in non-model teleosts [19]. Analysis of the transcriptome of the gonads of control female, hightemperature-treated female, and high-temperature-induced neomale tilapia identified a number of genes that may be involved in GSD + TE (genotypic sex determination + temperature effects), which should be useful for investigating the molecular mechanisms of GSD + TE in fish [20]. Study of the gonadal proteome in fish during sex reversal or gonadal differentiation, and the screening of important functional proteins related to reverse acquisition and gonadal differentiation are of great significance for the study of vertebrate sex determination and differentiation [21, 22]. GnRH immunization of mammals, such as mice, sheep, cattle, and pigs, can reduce the levels of $\mathrm{FSH}$ and $\mathrm{LH}$, and inhibit the development of the gonads, achieving artificial intervention in animal sex differentiation [12]. Intervention in fish sex differentiation by GnRH immunization, investigation of the mechanism of action of $\mathrm{GnRH}$ in regulating sex differentiation, and screening of sex determination factors are of great significance for uncovering the sex-differentiation and sex-controlling mechanisms. However, no transcriptomic or proteomic studies of tilapia gonad after $\mathrm{GnRH}$ immunization have been reported.

In this study, the gonadal transcripts of tilapia immunized with GnRHa were sequenced, and an average of $88.28 \%$ clean reads were mapped to the reference genome. Sun et al. sequenced the gonadal transcripts and 
mapped an average of $80.09 \%$ clean reads to the reference genome [20]. The reference genome of tilapia used by Sun et al. was Orenil1.1 (GCA_000188235.2) [20], while the reference genome used in this study was O_niloticus_UMD_NMBU (GCA_001858045.3). Orenil1.1 is a genome assembled by next-generation sequencing (Illumina), with a full length of $927,679,487$ bp, while O_niloticus_UMD_NMBU was assembled by third-generation sequencing (PacBio), with a full length of 1,005,681,550 bp. Combined with other genome parameters, the integrity of the O_niloticus_UMD_NMBU genome is better than that of the Orenil1.1 genome, resulting in better alignment in this study. The failure in aligning $11.72 \%$ clean reads to the reference genome in this study might have been due to factors such as wrongly sequenced reads remaining after quality control, interference of alternatively spliced genes, contamination by other genomes, and poor integrity and assembly of the reference genome.

In this study, 644 DEGs were identified by transcriptomic analysis, including 80 upregulated genes and 564 downregulated ones. Moreover, 1150 DEPs were identified by proteomic analysis, including 351 upregulated proteins and 799 downregulated ones. Overall, 209 genes showed consistent differential expression patterns at mRNA and protein levels, of which 9 were upregulated and 200 were downregulated. The results of the three kinds of analysis showed that the expression of gonadal genes was inhibited by GnRHa immunization in tilapia, and the functions of downregulated genes were mainly focused on single-organism process, binding, cellular process, metabolic process, and catalytic activity, while the main involved pathways include ECMreceptor interaction, focal adhesion, cardiac muscle contraction, and oxidative phosphorylation. It is notable that six DEGs are involved in the GnRH signaling pathway, and the expression of these six genes is downregulated, indicating that $\mathrm{GnRHa}$ immunization can inhibit the expression of genes related to the gonadotropin releasing hormone signal transduction pathway.

Forty-seven downregulated genes were obtained by combined analysis of the transcriptomic and proteomic data, among which the differential expression of zona pellucida sperm-binding protein 3 (ZPBP3), apolipoprotein A-I (apo A-I), and cytoplasmic 1 was most significant. Zona pellucida sperm binding protein (ZPBP) is closely related to sperm motility, capacitation, acrosome reaction, and sperm-egg binding. Studies have shown that ZPBP1 and ZPBP2 were mainly expressed in testicular tissue of mammals, while ZPBP3 was found in tilapia $[23,24]$. In this study, it was found that ZPBP3 could be expressed in the gonad of female tilapia, which may be related to the specific sex differentiation mechanism of fish. Meanwhile, the expression of ZPBP3 in gonad of tilapia was significantly downregulated after GnRHa immunization, indicating that ZPBP3 plays an important role in the gonad development of tilapia. Apo A-l is the major component of highdensity lipoprotein, which plays an important role in reverse cholesterol transport and lipid metabolism, and is also a very important innate immune molecule, providing a platform for the assembly of several immune complexes [25,26]. Previous studies showed that apo A-I was present in multiple tissues of Branchiostoma belcheri, and the expression of apo A-I mRNA was highest in the gonads; the expression of apo A-I mRNA increased significantly in the process of infection, suggesting that apo A-I may be involved in immune stress response and play an important role in the innate defense immune system of Amphioxus [27]. The apo A-I expression profile in Monopterus albus immunized with Aeromonas hydrophila showed that infection could downregulate the expression of apo A-I in the small intestine, spleen, and liver, indicating that apo A-I might be involved in the innate immune system of this species [28]. In this study, the expression of apo A-I in gonad of tilapia immunized with GnRHa was significantly downregulated, which also indicated that apo A-I plays an 
important role in the immune response of tilapia. Actin is one of the most highly conserved proteins in eukaryotic cells. It is mainly present in the cytoplasm, is the main component of cytoskeleton microfilaments, and is necessary for a variety of cell functions, such as the division, movement, and growth of cells [29]. Actin (cytoplasmic 1) can be expressed in several tissues of tilapia, but its expression level in gonad is much higher than that in other tissues, indicating that this gene may play an important role in gonad development and gonad functions of tilapia [24]. In this study, the expression of actin (cytoplasmic 1) in gonad of tilapia immunized with GnRHa was significantly downregulated, which indicated that GnRHa immunization could inhibit the expression of important genes involved in gonad development and provide a reference for revealing the mechanism of $\mathrm{GnRH}$ immunization.

\section{Conclusions}

To elucidate the mechanism behind the immunosuppressive effect of GnRHa on gonad development in tilapia, this study analyzed the transcriptome and proteome of tilapia gonad after GnRHa immunization. The results showed that, compared with that in the control group, the gonad gene expression after GnRHa immunization was significantly different, and the number of downregulated genes was significantly higher than that of the upregulated genes. Six differentially expressed genes involved in the GnRH signaling pathway were screened, all of which were downregulated, indicating that GnRHa immunization inhibited the expression of genes related to the gonadotropin releasing hormone signal transduction pathway in tilapia. In addition, several important functional genes related to $\mathrm{GnRHa}$ immunity were screened, which laid a foundation for revealing the mechanism behind the effect of $\mathrm{GnRH}$ on gonad development in tilapia. Further studies on the expression patterns of screened GnRHa immune-related genes and the verification of gene functions are currently underway.

\section{Methods}

\section{Fish and GnRHa immunization}

All female tilapia (Oreochromis niloticus) with average weight of $30.22 \pm 1.80 \mathrm{~g}$ were provided by the National Tilapia Seed Farm (Nanning, Guangxi, China). According to the amino acid sequence of tilapia $\mathrm{GnRH}$ in Uniprot database (entry name: Q76FQ2), we had designed and synthesized tilapia GnRHa (Pyr-His-Trp-Ser-TyrLeu-Arg-Pro-NHEt). The GnRHa antigen was prepared according to the method we reported before [13]. The tilapia were randomly divided into two groups. One group (the GnRHa-immunized group; T1) was immunized by intraperitoneal injection with $0.5 \mathrm{~mL} / \mathrm{fish}$ of GnRHa Freund's complete adjuvant antigen $(200 \mu \mathrm{g} / \mathrm{mL})$, followed by the same dose of GnRHa Freund's incomplete adjuvant antigen after 14 days. The other group (the control group; CK) was injected with the same volume of PBS emulsion. The samples were collected 10 weeks after the first immunization. Four replications were included in each group with 60 tilapia per replication, which were named T1-1, T1-2, T1-3, and T1-4 and CK-1, CK-2, CK-3, and CK-4. During the study, the water temperature of tilapia culture was kept at $27.5 \pm 1.5^{\circ} \mathrm{C}$, and the water was aerated continuously for $24 \mathrm{~h}$. The water was refreshed every 2 days and the fish were provided with feed equivalent to $3 \%$ of their body weight daily. The basic fish feed comprising soybean meal, fish meal, and flour was used as feed (purchased from Nanning Tongwei Feed Company; floating fish feed). 


\section{Sampling and gender identification}

Feeding was stopped $24 \mathrm{~h}$ prior to sampling. The sex of tilapia was judged according to the external genitalia. The fishes were anesthetized with MS222. Then, the complete gonad was isolated and washed with PBS. For each repetition, the gonads of three tilapia were mixed, put into an RNase-free cryotube, and stored at $-80{ }^{\circ} \mathrm{C}$ after freezing in liquid nitrogen.

\section{RNA extraction, RNA-seq library construction, and Illumina deep sequencing}

The total RNA of tissues was extracted using Trizol reagent (Invitrogen), in accordance with the manufacturer's instructions. Then, genomic DNA was removed from the RNA sample using DNase. Two microliters of total RNA was separated by $1 \%$ agarose gel electrophoresis to preliminarily determine the integrity and purity of RNA samples. Then, the concentration, quality, and integrity of RNA were determined using a NanoDrop 2000 spectrophotometer (Thermo Scientific) and an Agilent 2100 Bioanalyzer (Agilent Technologies). RNA samples with 260/280 nm absorbance ratios of approximately 2.0 and RNA integrity numbers (RIN) $>7.0$ were processed for RNA-seq.

The mRNA was enriched using oligo(dT) beads, and the enriched mRNA was fragmented into short fragments using fragmentation buffer and reverse-transcribed into CDNA with random primers. Second-strand cDNA was synthesized using DNA polymerase I, RNase $\mathrm{H}, \mathrm{dNTP}$, and buffer. Then, the cDNA fragments were purified with QiaQuick PCR extraction kit, end-repaired, poly(A)-added, and ligated to Illumina sequencing adapters. The ligation products were size-selected by agarose gel electrophoresis, PCR-amplified, and sequenced using Illumina HiSeq ${ }^{\text {Tm }} 4000$ by Gene Denovo Biotechnology Co. (Guangzhou, China).

\section{Bioinformatic analysis of RNA-seq data}

To acquire clean reads, the raw reads were filtered by removing reads containing adapters, reads containing more than $10 \%$ unknown nucleotides $(\mathrm{N})$, and low-quality sequences [reads containing more than $50 \%$ lowquality (Qvalue $\leq 10$ ) bases]. To avoid interference of ribosomal RNA, we mapped the clean reads to the ribosome database using bowtie [30] and removed the matched reads from the ribosome database. We mapped the remaining reads to the genome sequence of tilapia (GCF_001858045.2) using TopHat2 [31]. The sequencing data were deposited in the NCBI Sequence Read Archive under accession numbers SRR9937067SRR9937074. The aligned reads were assembled into transcripts using cufflinks, and the assembled transcripts were merged using cuffmerge [32]. The abundance of gene transcripts was calculated via FPKM (fragments per kilobase of transcript per million mapped reads) [33], and genes with mean abundance of $>0$ FPKM in any one of these samples were regarded as being expressed.

The raw read counts were used for differential expression analysis using edgeR [34]. Genes with fold change of FDR $<0.05, \mid \log _{2} \mathrm{FCl}>1$, and $\mathrm{p}<0.05$ were considered to be differentially expressed. In this study, the differentially expressed genes (DEGs) between the immunized group (T1) and the control group (CK) were analyzed. After obtaining the DEGs, Gene Ontology (GO) classification was performed on them using the GOseq R packages based on a Wallenius noncentral hypergeometric distribution [35], which can adjust for 
gene length bias in DEGs. The statistically significant enrichment of DEGs in KEGG pathways was tested using KOBAS software [36].

\section{Protein extraction, protein digestion, and separation high pH reverse phase}

Total proteins were extracted from the same samples as those for RNA-seq using the cold acetone method [37]. Protein quality was examined using SDS-PAGE. The Pierce ${ }^{\mathrm{TM}}$ BCA Protein Assay Kit (Thermo Scientific) was used to determine the concentration of protein. A total of $50 \mu \mathrm{g}$ of protein extracted from tilapia gonad was suspended in $50 \mu \mathrm{L}$ of solution, reduced by adding $1 \mu \mathrm{L}$ of $1 \mathrm{M}$ dithiothreitol at $55^{\circ} \mathrm{C}$ for $1 \mathrm{~h}$, and alkylated by adding $5 \mu \mathrm{L}$ of $20 \mathrm{mM}$ iodoacetamide in the dark at $37^{\circ} \mathrm{C}$ for $1 \mathrm{~h}$. Then, the sample was precipitated using $300 \mu \mathrm{L}$ of prechilled acetone at $-20^{\circ} \mathrm{C}$ overnight. The precipitate was washed twice with cold acetone and then resuspended in $50 \mathrm{mM}$ ammonium bicarbonate. Finally, the proteins were digested with sequence-grade modified trypsin (Promega) at a substrate/enzyme ratio of $50: 1$ (w/w) at $37^{\circ} \mathrm{C}$ for $16 \mathrm{~h}$.

\section{Data-dependent acquisition (DDA) mass spectrometry}

The peptide mixture of the eight samples was redissolved in buffer $\mathrm{A}$ ( $20 \mathrm{mM}$ ammonium formate in water, $\mathrm{pH}$ 10.0 , adjusted with ammonium hydroxide) and then fractionated by high $\mathrm{pH}$ separation using the Ultimate 3000 system (ThermoFisher Scientific) connected to a reverse-phase column (XBridge C18 column, $4.6 \mathrm{~mm} \times$ $250 \mathrm{~mm}, 5 \mu \mathrm{m}$; Waters Corporation). High pH separation was performed using a linear gradient, starting from $5 \% \mathrm{~B}(20 \mathrm{mM}$ ammonium formate in $80 \% \mathrm{ACN}, \mathrm{pH} 10.0$, adjusted with ammonium hydroxide) to $45 \% \mathrm{~B}$ in $40 \mathrm{~min}$. The column was re-equilibrated at the initial conditions for $15 \mathrm{~min}$. The column flow rate was maintained at $1 \mathrm{~mL} / \mathrm{min}$ and the column temperature was maintained at $30^{\circ} \mathrm{C}$. Ten fractions were collected; each fraction was dried in a vacuum concentrator for the next step.

The ten fractions were redissolved in $30 \mu \mathrm{L}$ of $\mathrm{C}(0.1 \%$ formic acid in water $)$ and analyzed by online nanospray LC-MS/MS on an Orbitrap Fusion Lumos (Thermo Fisher Scientific) coupled to a Nano ACQUITY UPLC system (Waters Corporation). A $10 \mu \mathrm{L}$ peptide sample was loaded onto the trap column (Acclaim PepMap C18, $100 \mu \mathrm{m} \times 2 \mathrm{~cm}$; Thermo Fisher Scientific) with a flow rate of $300 \mathrm{~nL} / \mathrm{min}$ and subsequently separated on the analytical column (Acclaim PepMap C18, $75 \mu \mathrm{m} \times 15 \mathrm{~cm}$ ) with a set gradient, from 5\% D (0.1\% formic acid in $A C N$ ) to $8 \%$ D in $3 \mathrm{~min}$; from $8 \% \mathrm{D}$ to $22 \% \mathrm{D}, 3-82 \mathrm{~min}$; from $22 \% \mathrm{D}$ to $35 \% \mathrm{D}, 82-106 \mathrm{~min}$; from $35 \% \mathrm{D}$ to $90 \%$ D, 106-118 min; maintained at $90 \%$ D for $5 \mathrm{~min}$; from $90 \% \mathrm{D}$ to $3 \% \mathrm{D}$ in $0.1 \mathrm{~min}$; and then maintained at $3 \% \mathrm{D}$ to $120 \mathrm{~min}$. The column flow rate was maintained at $500 \mathrm{~nL} / \mathrm{min}$ with a column temperature of $40{ }^{\circ} \mathrm{C}$. An electrospray voltage of $2.1 \mathrm{kV}$ versus the inlet of the mass spectrometer was used.

The mass spectrometer was run under data-dependent acquisition mode, and automatically switched between MS and MS/MS modes. The parameters were as follows: $(1) \mathrm{MS}$ : scan range $(\mathrm{m} / \mathrm{z})=350-1200$; resolution = 60,000; $\mathrm{AGC}$ target = 400,000; maximum injection time = $50 \mathrm{~ms}$; included charge states = 2-6; filter dynamic exclusion: exclusion duration = 30 s; and (2) HCD-MS/MS: resolution = 30,000; AGC target = 500,000; maximum injection time = $64 \mathrm{~ms}$; collision energy = 35\%; and stepped CE $=5 \%$.

\section{Quantification of proteins using data-independent acquisition (DIA) mass spectrometry}


The peptides of eight samples were redissolved in $30 \mu \mathrm{L}$ of $\mathrm{C}$ and analyzed by HPLC as mentioned above. The mass spectrometer was run under DIA mode, and automatically switched between MS and MS/MS modes. The parameters were as follows: $(1)$ MS: scan range $(\mathrm{m} / \mathrm{z})=350-1200$; resolution $=120,000$; $\mathrm{AGC}$ target $=$ 500,000; maximum injection time $=60 \mathrm{~ms}$; and (2) HCD-MS/MS: resolution $=50,000 ;$ AGC target $=1,000,000$; maximum injection time $=100 \mathrm{~ms}$; collision energy $=35 \%$; and stepped $\mathrm{CE}=5 \%$.

\section{Mass spectrometric data analysis}

Raw data of DDA were processed and analyzed by Spectronaut Pulsar 11.0 (Biognosys AG). Pulsar was set up to search the database of 0 . niloticus assuming trypsin as the digestion enzyme. Carbamidomethylation was specified as the fixed modification. Oxidation was specified as the variable modification. Raw data of DIA were processed and analyzed by Spectronaut Pulsar 11.0 (Biognosys AG) with the default parameters. After Student's t-test, differentially expressed proteins (DEPs) were filtered if their Qvalue was $<0.05$ and absolute AVG $\log _{2}$ ratio was $>0.58$.

\section{Protein functional annotation and enrichment analysis}

Proteins were annotated against the GO, KEGG, and COG/KOG databases to obtain their functions. Significant GO functions and pathways were examined among the DEPs with Qvalue $\leq 0.05$.

\section{Validation of DEGs by qRT-PCR}

To validate the DEGs obtained by RNA sequencing, qRT-PCR was carried out with the total RNA used for RNA sequencing to examine the expression of 6 DEGs (2 upregulated unigenes and 4 downregulated unigenes). In the qRT-PCR analysis, the $\beta$-actin gene was amplified as an endogenous control. All samples were tested in triplicate. Specific primers were designed by the Primer Express 3.0 Software (Applied Biosystems), and are listed in Table 4. The relative changes of gene expression were calculated by $2^{-\Delta \Delta C t}$ methods [38]. The value of log 2-fold change was used for graphing.

Table 4

Primer sequences used for quantitative real-time reverse transcription-PCR.

\begin{tabular}{|llll|}
\hline Transcript ID & Transcript name & Forward Primer & Reverse Primer \\
\hline ncbi_109194882 & uncharacterized & GCCATCACTGTTCCCATCCA & CACCCTCCGTAACCTCGTCT \\
\hline ncbi_109195722 & uncharacterized & GCCATCACTGTTCCCATCCA & CACCCTCCGTAACCTCGTCT \\
\hline ncbi_100695709 & EGFR & ATGCTGTGGACGCTGATGAA & GATGCTGCTGTTGAGGCTTG \\
\hline ncbi_100695964 & MT1 & GGATAAGTGGTTCTGGCGGG & GGTGTAGTAGAGAGCAGCGT \\
\hline ncbi_100700606 & MMP2 & GCTACCCGAAAAGGTTGTCC & TGATTTCACCCAACTTCACGAT \\
\hline ncbi_100703685 & c-Jun & ACCTCAGCCCCCACTATGTC & GCTCGGAGTTCTGTGACTTTAGG \\
\hline- & actb & CTTCAACACCCCCGCCA & ATGTCACGCACGATTTCCCT \\
\hline
\end{tabular}

\section{Abbreviations}


GnRHa: gonadotropin-releasing hormone analog; DIA: data-independent acquisition; FSH: follicle-stimulating hormone; LH: luteinizing hormone; FDR: false discovery rate; FC: fold change; T1: immunized group; CK: control group; DEGs: differentially expressed genes; DEPs: differentially expressed proteins; DDA: datadependent acquisition; GO: Gene Ontology; KEGG: Kyoto Encyclopedia of Genes and Genomes; qRT-PCR: quantitative real-time reverse transcription-PCR; FPKM: fragments per kilobase of transcript per million mapped reads.

\section{Declarations}

\section{Ethics approval and consent to participate}

All experiments were conducted under the Guidelines of the Laboratory Animals Use and Care of China. This study was approved by the Committee on the Ethics of Animal Experiments of Guangxi Academy of Fishery Sciences.

\section{Consent to publish}

Not applicable.

\section{Availability of data and materials}

The RNA-seq data in this study were available at NCBI Sequence Read Archive with the accession number of SRR9937067-SRR9937074 (https://www.ncbi.nlm.nih.gov/sra/).

\section{Competing interests}

The authors declare that they have no competing interests.

\section{Funding}

This work was supported by Science and Technology Fund of Guangxi Province (Grant no. AB16380073), National Modern Agricultural Technology System (Grant no. nycytxgxcxtd-08). The funding bodies had no role in the design of the study and collection, analysis, and interpretation of data and in writing the manuscript.

\section{Authors' Contributions}

RW, LW, and HY conceived and designed the study. RW, LW, HM, ML, and ZC performed the experiments. RW, $X D, L Z$, and $Y L$ analyzed the data and drafted the manuscript with LH; RW, LW, HY, and TC wrote the manuscript. All authors read, revised extensively, and gave final approval of the manuscript.

\section{Acknowledgement}

We thank Liwen Bianji, Edanz Group China (www.liwenbianji.cn/ac), for editing the English text of a draft of this manuscript.

\section{References}


1. Turkstra JA, van der Staay FJ, Stockhofe-Zurwieden N, Woelders H, Meloen RH, Schuurman T. Pharmacological and toxicological assessment of a potential $\mathrm{GnRH}$ vaccine in young-adult male pigs. Vaccine 2011; 29(21):3791-3801.

2. Gorbman A, Sower SA. Evolution of the role of GnRH in animal (Metazoan) biology. Gen Comp Endocrinol 2003; 134(3):207-213.

3. Fraser HM. Antifertility effects of GnRH. J Reprod Fertil 1982; 64(2):503-515.

4. Mylonas CC, Zohar Y. Use of GnRHa-delivery systems for the control of reproduction in fish. Reviews in Fish Biology \& Fisheries 2000; 10(4):463-491.

5. Oonk HB, Turkstra JA, Schaaper WM, Erkens JH, Schuitemaker-de Weerd MH, van Nes A et al. New GnRHlike peptide construct to optimize efficient immunocastration of male pigs by immunoneutralization of GnRH. Vaccine 1998; 16(11-12):1074-1082.

6. Thompson DL. Immunization against GnRH in male species (comparative aspects). Anim Reprod Sci 2000; 60-61:459-469.

7. Quaresma MAG, Antunes IC, Ribeiro MF, Prazeres S, Bessa RJB, da Costa PM. Immunocastration as an alternative to caponization: evaluation of its effect on body and bone development and on meat color and composition. Poult Sci 2017; 96(10):3608-3615.

8. Zohar Y, Munoz-Cueto JA, Elizur A, Kah O. Neuroendocrinology of reproduction in teleost fish. Gen Comp Endocrinol 2010; 165(3):438-455.

9. Gothilf Y, Munoz-Cueto JA, Sagrillo CA, Selmanoff M, Chen TT, Kah O et al. Three forms of gonadotropinreleasing hormone in a perciform fish (Sparus aurata): complementary deoxyribonucleic acid characterization and brain localization. Biol Reprod 1996; 55(3):636-645.

10. Senthilkumaran B, Okuzawa K, Gen K, Ookura T, Kagawa H. Distribution and seasonal variations in levels of three native GnRHs in the brain and pituitary of perciform fish. J Neuroendocrinol 1999; 11(3):181-186.

11. Wang M, Lu M. Tilapia polyculture: a global review. Aquaculture Research 2016; 47(8):2363-2374.

12. Lee BY, Hulata G, Kocher TD. Two unlinked loci controlling the sex of blue tilapia (Oreochromis aureus). Heredity (Edinb) 2004; 92(6):543-549.

13. Yang $H$, Huang G, Lv M, Lin $Y$, Wang R, Zeng $L$ et al. Immune effects of Alarelin on ovarian development and $\mathrm{GnRH}$ receptor mRNA expression levels of pituitary in tilapia (Oreochromis niloticus). Turkish Journal of Fisheries and Aquatic Sciences 2019; 19(4):289-296.

14. Abdelrahman H, ElHady M, Alcivar-Warren A, Allen S, Al-Tobasei R, Bao L et al. Aquaculture genomics, genetics and breeding in the United States: current status, challenges, and priorities for future research. BMC Genomics 2017; 18(1):191.

15. Mazzeo MF, Siciliano RA. Proteomics for the authentication of fish species. J Proteomics 2016; 147:119124.

16. Guo H, Zhang J, Wang Y, Bu C, Zhou Y, Fang Q. Comparative Proteomic Analysis of Lysine Acetylation in Fish CIK Cells Infected with Aquareovirus. Int J Mol Sci 2017; 18(11).

17. Ye H, Lin Q, Luo H. Applications of transcriptomics and proteomics in understanding fish immunity. Fish Shellfish Immunol 2018; 77:319-327. 
18. Sun S, Cai J, Tao W, Wu L, Tapas C, Zhou L et al. Comparative transcriptome profiling and characterization of gene expression for ovarian differentiation under RU486 treatment. Gen Comp Endocrinol 2018; 261:166-173.

19. Tao W, Yuan J, Zhou L, Sun L, Sun Y, Yang S et al. Characterization of gonadal transcriptomes from Nile tilapia (Oreochromis niloticus) reveals differentially expressed genes. PLoS One 2013; 8(5):e63604.

20. Sun LX, Teng J, Zhao Y, Li N, Wang H, Ji XS. Gonad Transcriptome Analysis of High-Temperature-Treated Females and High-Temperature-Induced Sex-Reversed Neomales in Nile Tilapia. Int J Mol Sci 2018; 19(3).

21. Sheng Y, Zhao W, Song Y, Li Z, Luo M, Lei Q et al. Proteomic analysis of three gonad types of swamp eel reveals genes differentially expressed during sex reversal. Sci Rep 2015; 5:10176.

22. Groh KJ, Schonenberger R, Eggen RI, Segner H, Suter MJ. Analysis of protein expression in zebrafish during gonad differentiation by targeted proteomics. Gen Comp Endocrinol 2013; 193:210-220.

23. Yatsenko AN, O'Neil DS, Roy A, Arias-Mendoza PA, Chen R, Murthy LJ et al. Association of mutations in the zona pellucida binding protein 1 (ZPBP1) gene with abnormal sperm head morphology in infertile men. Mol Hum Reprod 2012; 18(1):14-21.

24. Brawand D, Wagner CE, Li YI, Malinsky M, Keller I, Fan S et al. The genomic substrate for adaptive radiation in African cichlid fish. Nature 2014; 513(7518):375-381.

25. Chung H, Randolph A, Reardon I, Heinrikson RL. The covalent structure of apolipoprotein A-I from canine high density lipoproteins. J Biol Chem 1982; 257(6):2961-2967.

26. Shiflett AM, Bishop JR, Pahwa A, Hajduk SL. Human high density lipoproteins are platforms for the assembly of multi-component innate immune complexes. J Biol Chem 2005; 280(38):32578-32585.

27. Qu Q: The cloning, expression and antimicrobial activity analysis of apoA-I of Branchiostoma belcheri (in Chinese). 2017.

28. Kan Y, Jiang A, Sun W, Li W. Gene Structure and Expression of Apo-A1 Gene f rom Swamp Eel. Fisheries Science 2016; 35(6):697-701 (in Chinese).

29. Field CM, Lenart P. Bulk cytoplasmic actin and its functions in meiosis and mitosis. Curr Biol 2011; 21(19):R825-830.

30. Langmead B, Salzberg SL. Fast gapped-read alignment with Bowtie 2. Nat Methods 2012; 9(4):357-359.

31. Kim D, Pertea G, Trapnell C, Pimentel H, Kelley R, Salzberg SL. TopHat2: accurate alignment of transcriptomes in the presence of insertions, deletions and gene fusions. Genome Biol 2013; 14(4):R36.

32. Ghosh S, Chan CK. Analysis of RNA-Seq Data Using TopHat and Cufflinks. Methods Mol Biol 2016; 1374:339-361.

33. Trapnell C, Williams BA, Pertea G, Mortazavi A, Kwan G, van Baren MJ et al. Transcript assembly and quantification by RNA-Seq reveals unannotated transcripts and isoform switching during cell differentiation. Nat Biotechnol 2010; 28(5):511-515.

34. Robinson MD, McCarthy DJ, Smyth GK. edgeR: a Bioconductor package for differential expression analysis of digital gene expression data. Bioinformatics 2010; 26(1):139-140.

35. Young MD, Wakefield MJ, Smyth GK, Oshlack A. Gene ontology analysis for RNA-seq: accounting for selection bias. Genome Biol 2010; 11(2):R14. 
36. Mao X, Cai T, Olyarchuk JG, Wei L. Automated genome annotation and pathway identification using the KEGG Orthology (KO) as a controlled vocabulary. Bioinformatics 2005; 21(19):3787-3793.

37. Wu X, Xiong E, Wang W, Scali M, Cresti M. Universal sample preparation method integrating trichloroacetic acid/acetone precipitation with phenol extraction for crop proteomic analysis. Nat Protoc 2014; 9(2):362374.

38. Livak KJ, Schmittgen TD. Analysis of relative gene expression data using real-time quantitative PCR and the 2(-Delta Delta C(T)) Method. Methods 2001; 25(4):402-408.

\section{Figures}

\section{-Upregulated Downregulated}

1200

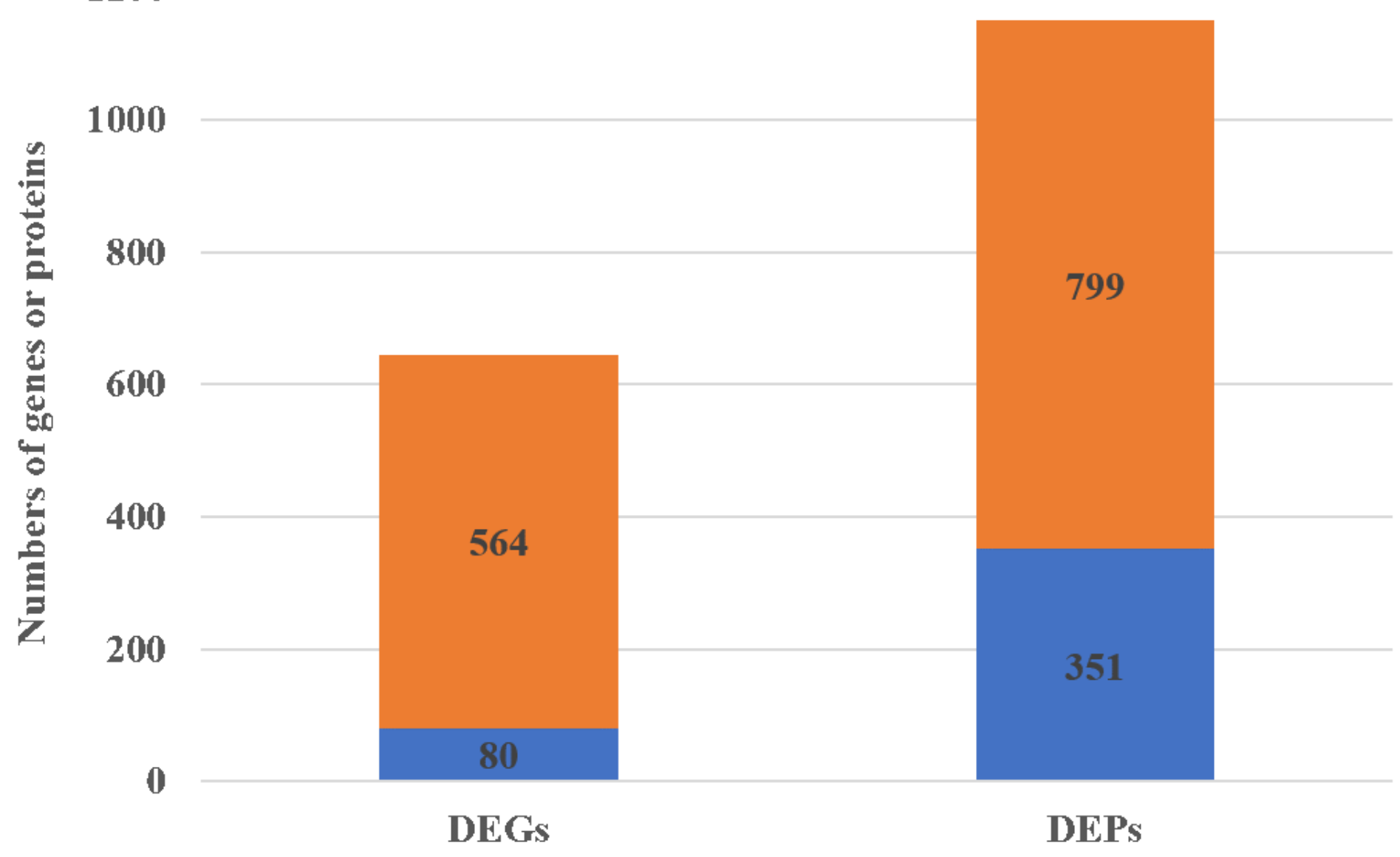

Figure 1

The genes and proteins differentially expressed between the immunized group and the control group. 


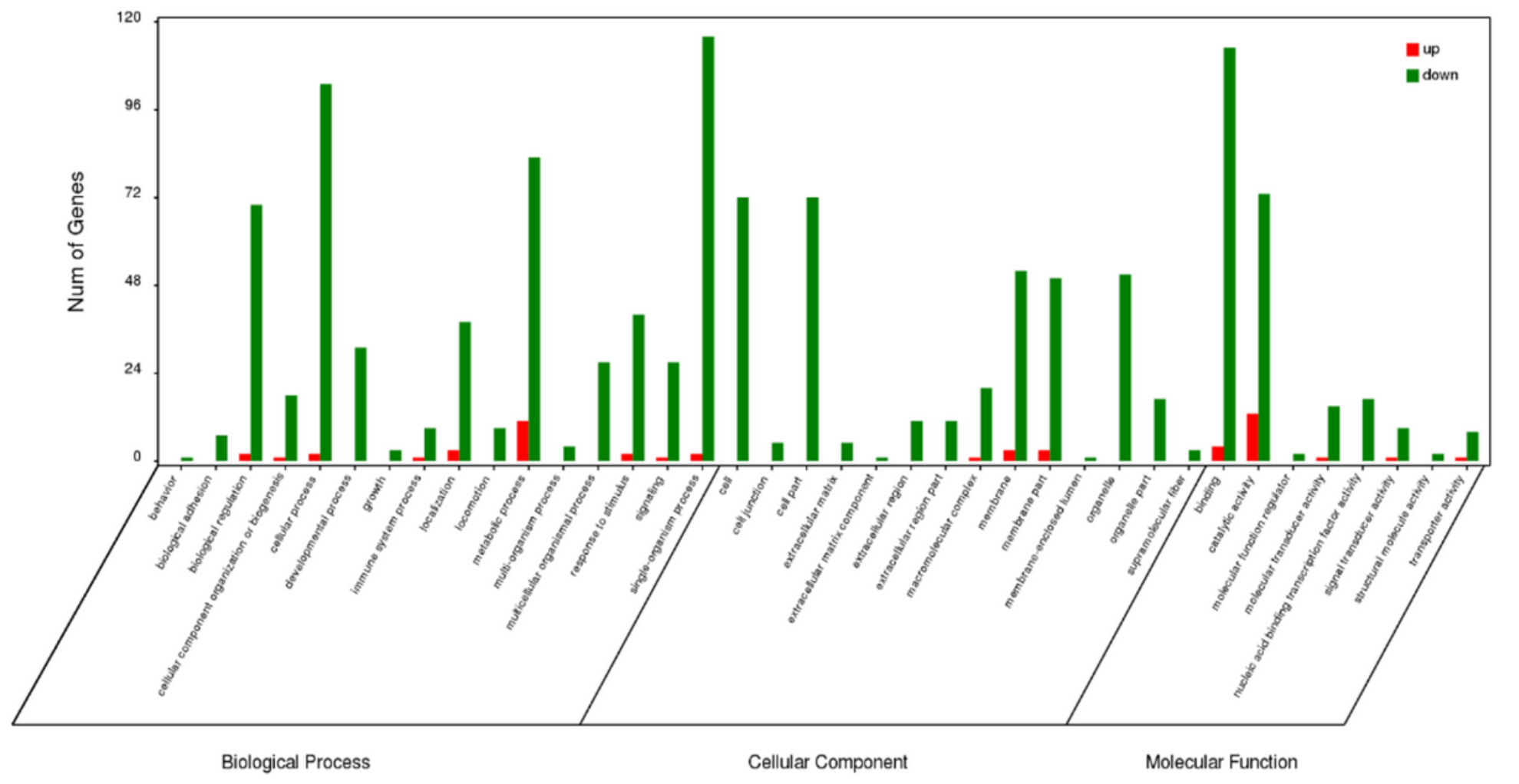

Figure 2

GO classification of genes differentially expressed between the immunized group and the control group. 


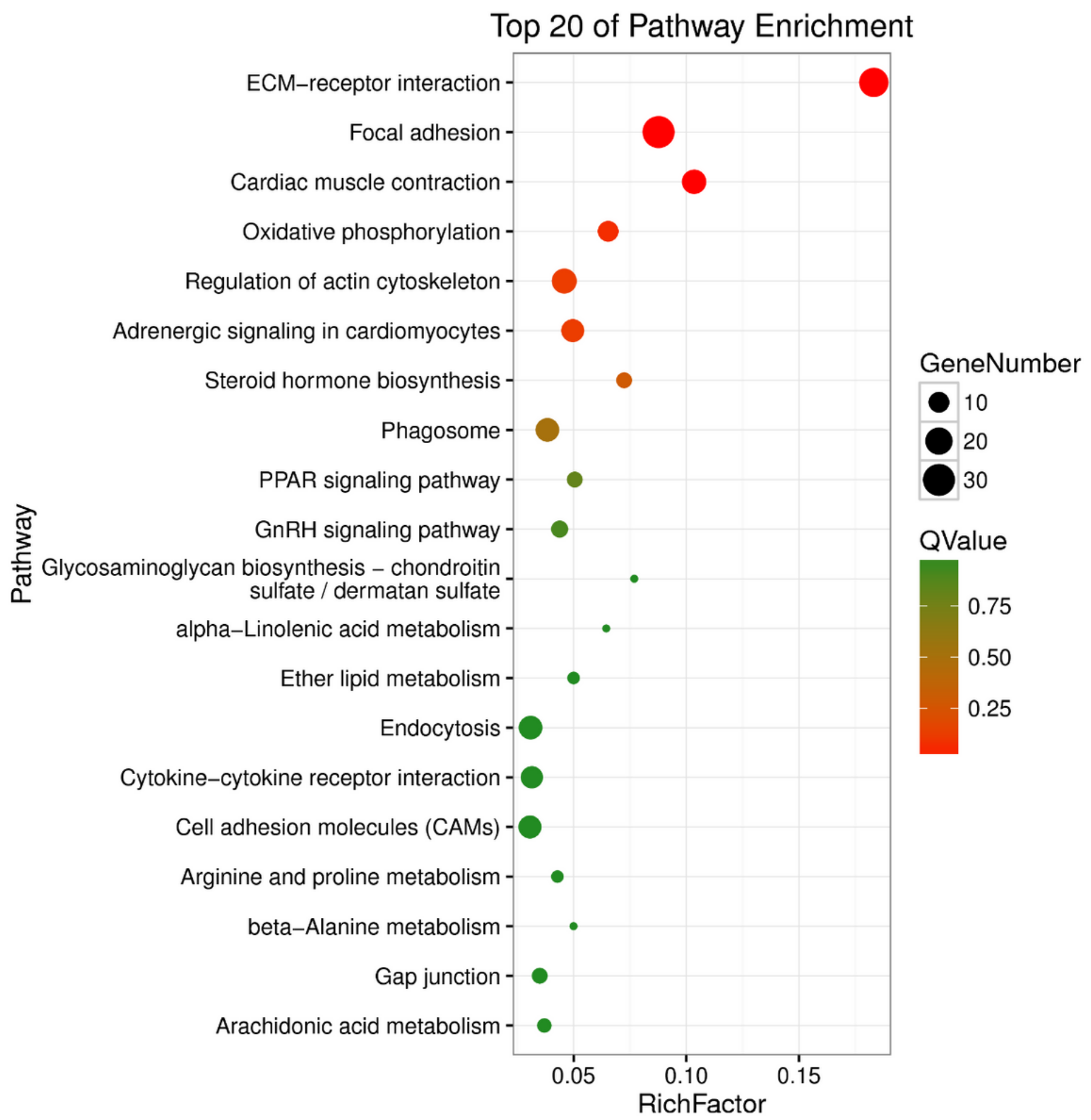

Figure 3

Enrichment of DEGs in KEGG pathways. 


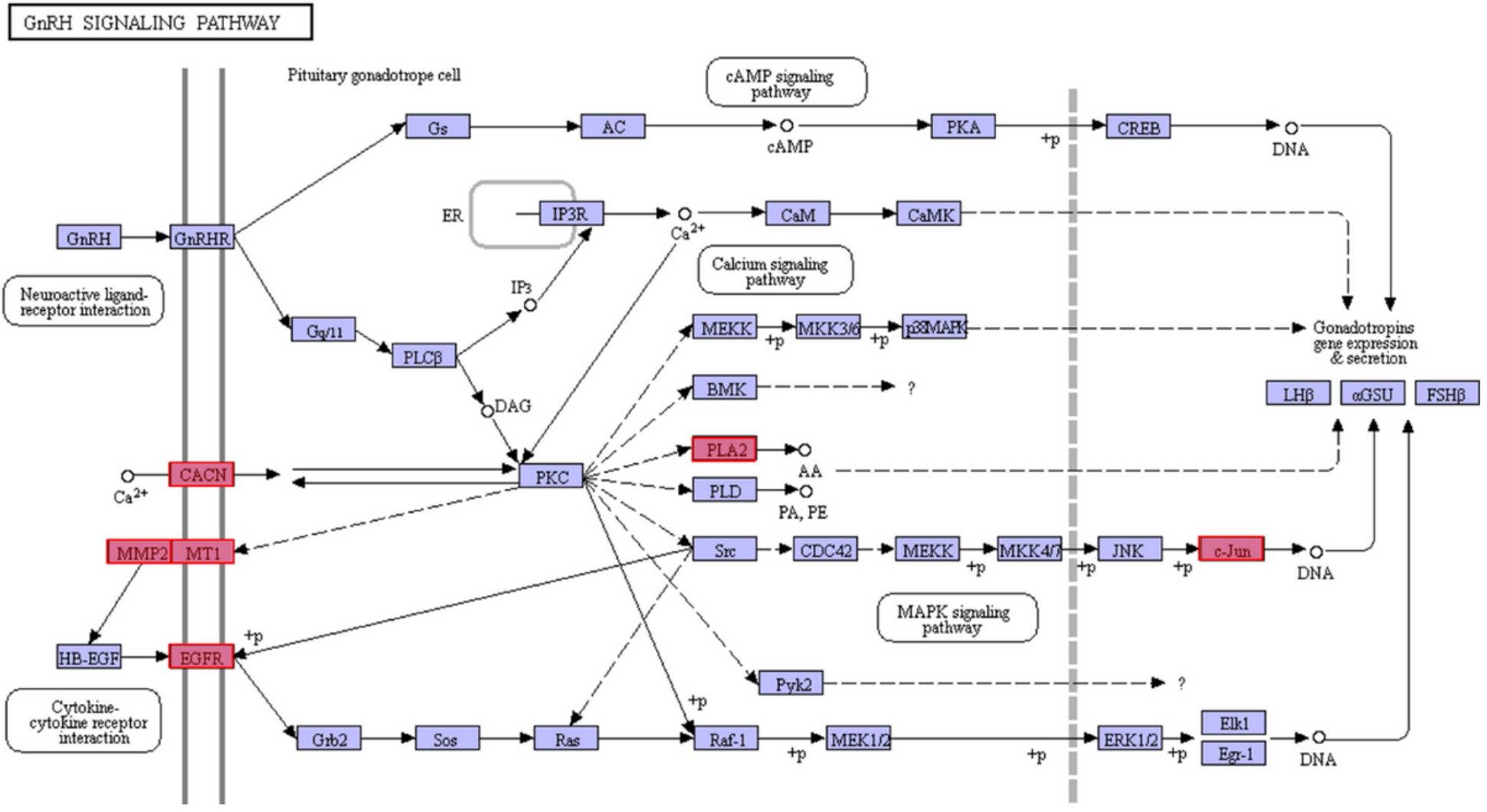

\section{Figure 4}

The location of the six genes in the GnRH signaling pathway.

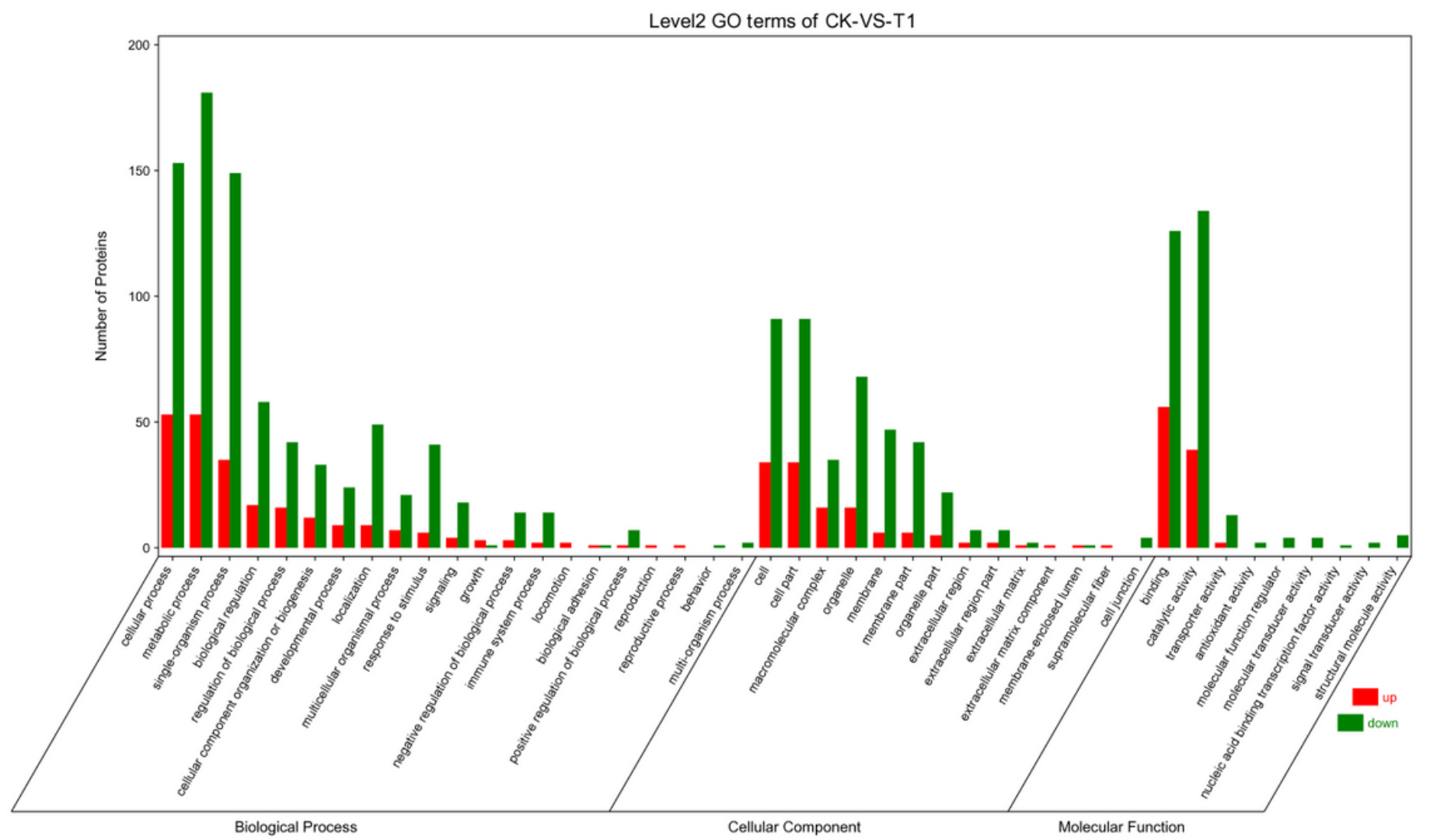

Figure 5 
GO classification of DEPs between the immunized group and the control group.

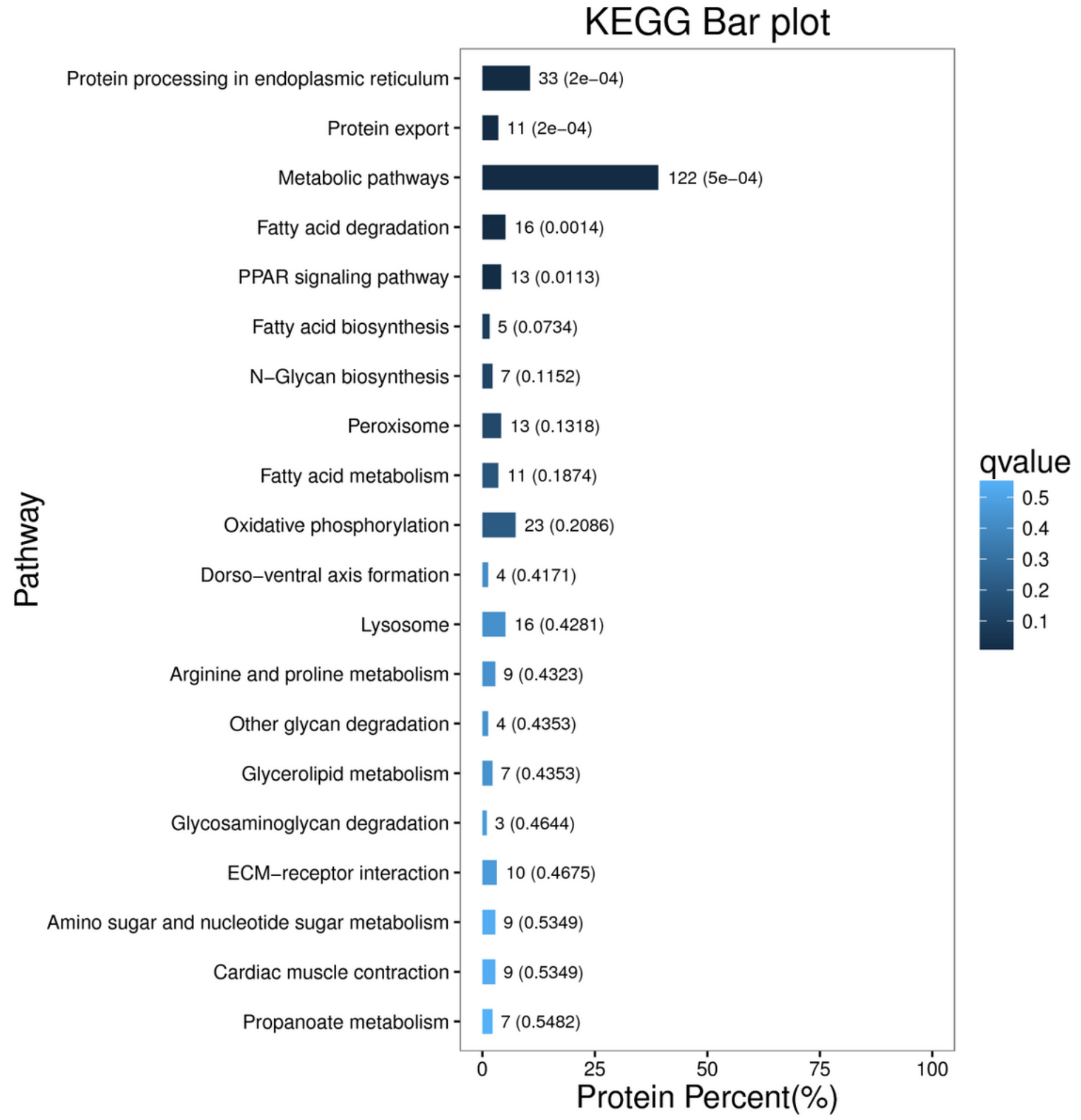

Figure 6

Enrichment of DEPs in KEGG pathways. 


\section{pearson correlation: 0.0851 p-value:0}

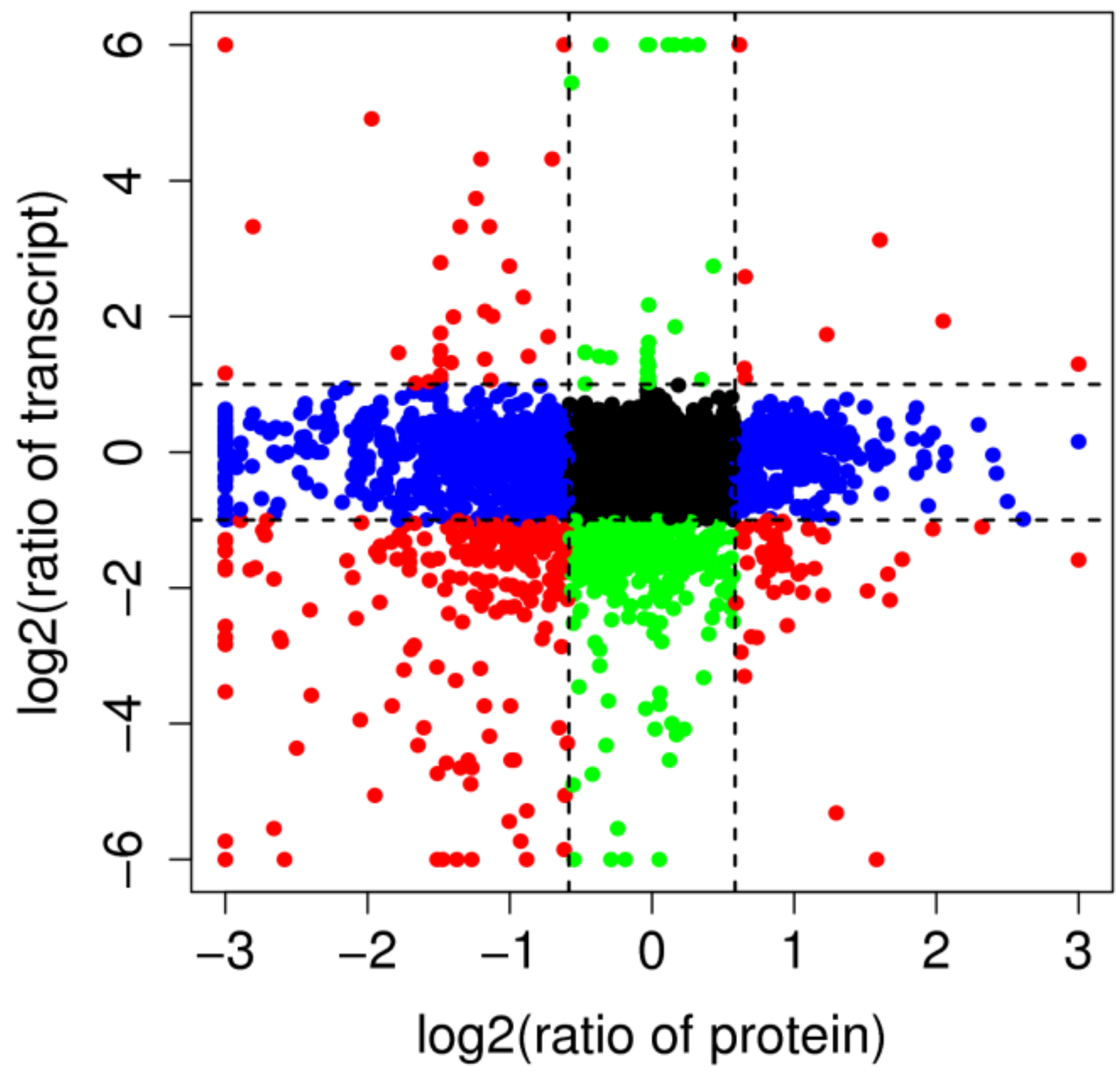

Figure 7

Correlation analysis of the protein and mRNA expression between the immunized group and the control group. The $x$-axis represents the log2 value of the fold differential gene expression, the $y$-axis represents the log2 value of the fold differential protein expression, and the dotted line indicates the threshold of significant differential expression. 


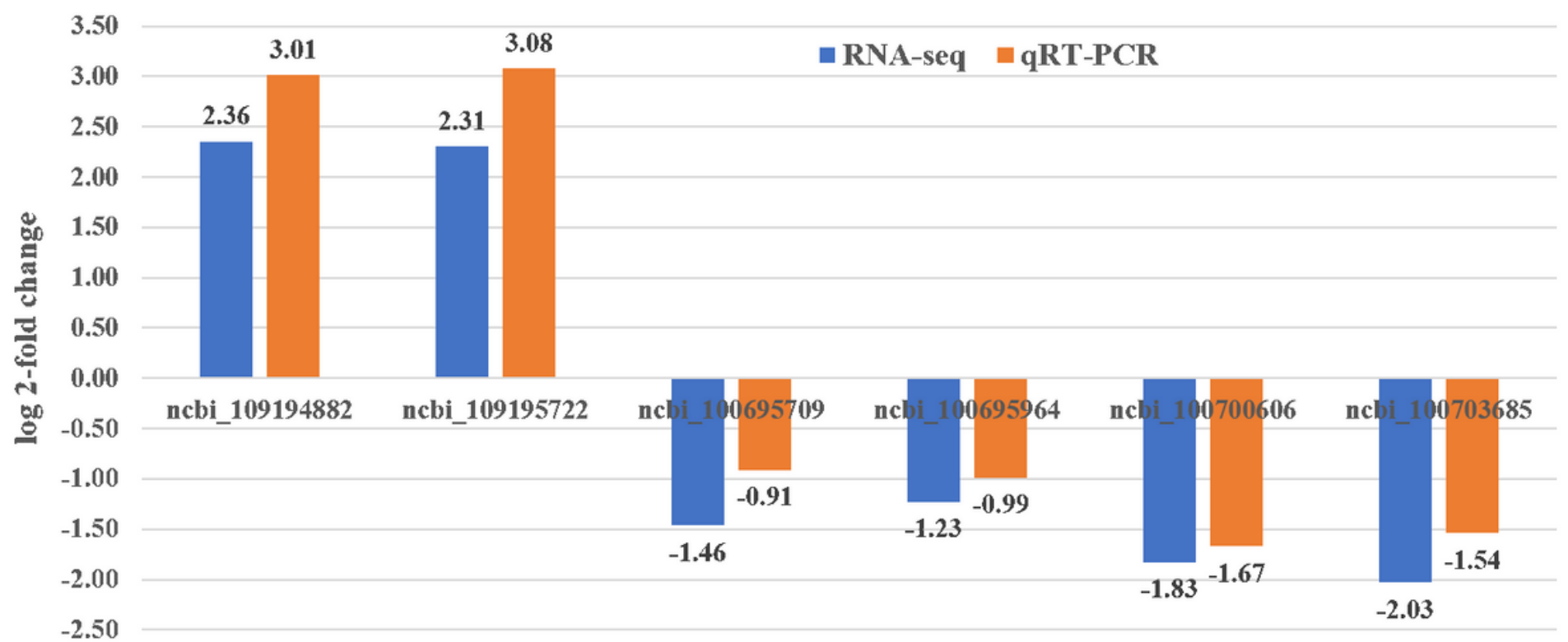

Figure 8

Comparison of the expression profiles of six selected genes as determined by RNA-seq and qRT-PCR.

\section{Supplementary Files}

This is a list of supplementary files associated with this preprint. Click to download.

- NC3RsARRIVEGuidelinesChecklist2014.pdf 